\title{
A KING ON THE MOVE: \\ THE PLACE OF AN ITINERANT COURT IN \\ CHARLEMAGNE'S GOVERNMENT
}

\section{Rosamond McKitterick}

In 1965, Adolf Gauert published a now famous map of Charlemagne's itinerary. It was produced in association with the Council of Europe's Charlemagne exhibition at Aachen and was a remarkable piece of reconstruction and investigation of battlefields and military camps, episcopal sees, monasteries and royal residences, and even the site of the canal Charlemagne tried to build to connect the Rhine and Danube rivers. The map claimed to illustrate how the king at one time or another throughout his reign moved right across western Europe, from the Pyrenees to the Elbe, from the English Channel almost to the Danube Bend, and across the Alps as far south as Capua. ${ }^{1}$ This picture of a king on the move accorded with the received understanding of itinerant kingship, developed in relation to the Ottonian and Salian rulers of Germany in the late tenth and eleventh century and often extrapolated to many other medieval realms. ${ }^{2} \mathrm{I}$ shall argue in this paper that such an understanding of Charlemagne as an itinerant king in the technical sense is simply inappropriate in relation to early Carolingian government. I want to challenge in particular the validity of one category of information on which Gauert relied to map the king's movements. This is the charter evidence, though in this respect Gauert was simply following standard practice in all studies of medieval rulers. In every existing study of a king's movements in the Middle Ages, it is assumed that the charter or royal diploma in the king's name is also confirmation of the king's presence. I shall suggest here that we should abandon this assumed correlation, and that once we have done

1 Adolf Gauert, 'Zum Itinerar Karls des Grossen', in: Karl der Große I Persönlichkeit und Geschichte I, W. Braunfels, ed. (Darmstadt 1965) pp. 307-321, between pp. 320 and 321.

${ }^{2}$ Conrad Peyer, 'Das Reisekönigtum des Mittelalters', Vierteljahrschrift für Sozialund Wirtschaftsgeschichte 51 (1964) pp. 1-21. See Eckhard Müller-Mertens, Die Reichsstruktur im Spiegel der Herrschaftspraxis Ottos des Großen, Forschungen zur mittelalterlichen Geschichte 25 (Berlin 1980). 
so, a very different picture of Charlemagne's itinerary between 768 and 814 , and consequently of his government, emerges.

Let me first explain how itinerant kingship is usually defined. It is a 'form of government in which a king carries out all the administrative functions and symbolic representations of governing by periodically or constantly travelling throughout the areas of his dominion. ${ }^{3}$ Thus it is not merely the ceremonial circumambulation of the royal progress to take symbolic possession of the kingdom, but actually a means of ruling. The king's subjects came to him in the places he visited. The iter was also a vehicle for the king's sacrality in the Ottonian period. ${ }^{4}$ The itinerary is thought to reflect not only the relationship between the importance of personality and personal power, regarded as an essential characteristic of medieval kings, but also the limited extent of the use of writing in government. Indeed, both the size of the kingdom and poor written communications have been posited as strong determining factors for the practice of itinerant kingship. Two other interlocking elements have been identified. The first is the notion of the palace as part of an economic system. It has been assumed, for the Carolingian period as well as for the Ottonian, that the king would not use his own resources from the royal estates and that anyone coming to a royal palace would expect to be fed by the king. ${ }^{5}$ Such a focus on the economic logistics of provision has sometimes become confused with necessity, so that a persistent image has been created of the king and his court as nomadic pastoralists or even a plague of locusts eating up the local produce and constantly on the move in search of new pasture. The Carolingians are even claimed to have had to renounce the idea of a fixed centre of government for economic reasons, and to content themselves with different royal residences. ${ }^{6}$ This does not make sense for the richly endowed early Carolingian rulers and what has been pieced together about the royal estates in the Frankish heartlands as well as on newly confiscated land from Westphalian, Saxon, and Bavarian landholders. Most crucially, discussions of the king's

${ }^{3}$ John Bernhardt, Itinerant and Royal Monasteries in Early Medieval Germany, c. 936-1075 (Cambridge 1993) p. 45.

${ }^{4}$ Bernhardt, Itinerant and Royal Monasteries, p. 293.

${ }^{5}$ Einhard, Epistolae, K. Hampe, ed., MGH Epp V (Berlin 1899) Ep. 5, pp. 111-112.

${ }^{6}$ Carlrichard Bruhl, "Remarques sur les notions du 'capitale' et du 'residence' pendant le haut moyen âge", Journal des savants (1967) pp. 195-215; reprinted in idem, Aus Mittelalter und Diplomatik. Gesammelte Aufsätze 2 vols. (Hildesheim 1989) vol. 1, pp. 115-137, at p. 207. 
economic needs have rarely taken the remarkable wealth of the Carolingian royal estates and the extensive forest support for hunting and fishing, in proximity to agricultural and pastoral land, into account: ${ }^{7}$ it was not the need for food which governed the king's movements. ${ }^{8}$

If we consider the territory inherited, conquered, annexed, or attached as tributary regions by treaty in the course of Charlemagne's reign, a rough categorization of the king's movements can be made. The places from the Rhine eastwards into Thuringia, Westphalia and Saxony are mostly linked with the Saxon campaigns recorded in many different sets of Frankish annals. Those in Italy reflect the conquest of the Lombard kingdom and subsequent interventions by Charlemagne thereafter in the affairs of the Lombard kingdom, Benevento and the Papacy. The little group in the Pyrenees includes the site of the famous defeat, traditionally located at Roncesvalles, which inspired the later Chanson de Roland, and the palaces in Bavaria and the camps placed in the middle Danube region witness to Charlemagne annexation of his cousin Tassilo's Duchy of Bavaria and his triumph over the Avars. Apart from these military campaigns, intermittent visits to other places are recorded in some of the narrative and documentary sources of the reign.

There are a number of difficulties with this representation of the king's movements within his own domains. Gauert's map could not explain without further commentary either the duration or the reason for the visits and travels of Charlemagne, and how much the pattern of movement may have changed in the course of his reign. Although some of these visits, as in Regensburg in 791-793 are prolonged, the pattern does not make a powerful case for a king ruling by means of his physical presence in the areas under Frankish rule beyond the Rhineland and Moselle region. Only in 787, 800-801 (mostly in Italy) and 791-3, when he spent such an extended period in Bavaria, did Charlemagne apparently not reside in or cross either the MeuseMoselle region (Aachen-Liège down to Metz) or the Rhineland-Main areas (Mainz, Ingelheim, Worms, Frankfurt). In many years his travelling is between and within these regions, even if only for the winter,

\footnotetext{
7 Wolfgang Metz, Zur Erforschung des karolingischen Reichsgutes, Erträge der Forschung 4 (Darmstadt 1971).

${ }^{8}$ R. Hennebicque (R. Le Jan), 'Espaces sauvages et chasses royale dans le Nord de la France', Revue du Nord 62 (1980) pp. 35-57, and E. Ewig, 'Les Ardennes au haut moyen âge', Ancien pays et assemblées d'états 28 (1963) pp. 3-38.
} 
Christmas, and/or Easter. This of course includes the years in which he crosses the Rhineland region in order to reach Saxony.

If the military campaigns are left out of consideration, it would appear that the king travelled mostly within the Frankish heartlands, and that many regions of his kingdom were never honoured by his presence. The implications of this are discussed further below but let us first address the practical matter of the distances and logistics of travelling involved. For this I offer estimates based on the information for motorists supplied by the Netherlands website Routenet.nl (with downloadable maps of all recommended routes). This may give some indication of distances, even if it can tell us nothing about the time absorbed by the journey, the speed of travel, the terrain, the conditions of the roads (ranging from local tracks to the extensive network of old Roman roads, many of which were maintained, at least those close to towns), the journeys Charlemagne took by boat on such major rivers as the Rhine, Moselle and Main rivers (as in 793 to Würzburg ${ }^{9}$ ) instead of overland, or the weather. Still less do we know about any of the detours necessary to find fords and bridges to cross rivers, and the scheduled and, no doubt, unscheduled stops on the way to talk to people, listen to petitions, eat, rest, pray and the like. It should be noted in passing that many of the arterial roads of western Europe still follow the routes of the old Roman roads, so the Routenet.nl suggestions about the distances involved may not be so very wide of the mark. ${ }^{10}$ We can probably assume that Charlemagne himself would have travelled on horseback overland, that there would have been faster riders with the party to carry messages and warn a place of the imminence of the king's arrival, and possibly a slower part of the cavalcade travelling by road with baggage on horses or mules, or in carts, or by water on barges. A conservative estimate might therefore be a speed of thirty kilometres a day. ${ }^{11}$

\footnotetext{
9 Annales Regni Francorum (ARF), Friedrich Kurze, ed. (Hannover 1895, 1909, 1950), p. 92.

10 See the Barrington Atlas of the Greek and Roman World (Princeton 2000), Maps 7, 10-19, 39-45.

${ }^{11}$ Le Jan, 'Espaces sauvages', also uses the computation of thirty kilometres per day. Michael McCormick, 'Pippin III, the embassy of Caliph al Mansur, and the Mediterranean world', in: Die Dynastiewechsel von 751. Vorgeschichte, Legitimationsstrategien und Erinnerung, Matthias Becher and Jörg Jarnut, eds. (Münster 2004) pp. 221-242, based his calculations of travel in the eighth century on information relating to the American civil war and army manoeuvres in the nineteenth century, and calculated similarly, namely, twenty-five miles per day.
} 
In 769, for example, Charlemagne, having reached Fronsac near Bordeaux, then travelled to somewhere beyond the Garonne river to the palace at Worms. From Fronsac to Worms is $1081 \mathrm{~km}$ or 34 days. In 774 one journey was from Pavia to Ingelheim, a distance of $701 \mathrm{~km}$ or about 24 days, but possibly using Worms as a stopping place, which is $46 \mathrm{~km}$ from Ingelheim (one very long day or two shorter ones). In 782, one journey was from Thionville to Paderborn, that is, $423 \mathrm{~km}$ or a fortnight, and in 788 Charlemagne's travels included the $574 \mathrm{~km}$ trip from Regensburg to Aachen (19 days) and in 795 from Aachen to Mainz, that is, $240 \mathrm{~km}$ ( 8 days).

If we follow the route of the round trip recorded in the Royal Frankish annals for 800 and 801 , the estimate is the following:

\begin{tabular}{|c|c|c|}
\hline From Aachen to Boulogne & $372 \mathrm{~km}$ & (13 days) \\
\hline From Boulogne to Rouen & $183 \mathrm{~km}$ & (6 days) \\
\hline From Rouen to Tours & $354 \mathrm{~km}$ & (12 days) \\
\hline From Tours to Orleans & $116 \mathrm{~km}$ & (4 days) \\
\hline From Orleans to Paris & $130 \mathrm{~km}$ & (5 days) \\
\hline From Paris to Aachen & $420 \mathrm{~km}$ & (14 days) \\
\hline From Aachen to Mainz & $40 \mathrm{~km}$ & (8 days) \\
\hline From Mainz to Ivrea & 696 km (via Strasbourg and Basel) & (23 days) \\
\hline From Ivrea to Rome & $678 \mathrm{~km}$ (via Florence) & (22 days) \\
\hline From Rome to Spoleto & $134 \mathrm{~km}$ & (5 days) \\
\hline From Spoleto to Ravenna & $237 \mathrm{~km}$ & (8 days) \\
\hline From Ravenna to Pavia & $282 \mathrm{~km}$ & (10 days) \\
\hline From Pavia to Ivrea & $148 \mathrm{~km}$ & (5 days) \\
\hline From Ivrea to Aachen & $894 \mathrm{~km}$ & (30 days) \\
\hline
\end{tabular}

The grand total is $4885 \mathrm{~km}$ which would involve approximately 165 days on the road. I have calculated the average distance between 794 and 804 as over a thousand kilometres per annum. Between 805 and 814, the average is 460 kilometres per annum (only 15 days), including the expedition to Saxony in $810(800 \mathrm{~km})$ and the years 809 and $812-814$ when only hunting trips to the Ardennes, a short distance of about one hundred kilometres from Aachen, are recorded. ${ }^{12}$

It is self-evident that none of these places can be reached from the one before it in a day. It is necessary, therefore, to envisage an entire

\footnotetext{
${ }^{12}$ Le Jan, 'Espaces sauvages', p. 47.
} 
network of stopping places on the way. ${ }^{13}$ For the most part we can only guess at the planning involved in terms of packing and unpacking weapons, clothes and possibly bedding and utensils as well, the supply of fresh mounts en route, giving notice of intended arrival or ensuring sufficient food, drink and firewood for the entourage (whatever its size) and their animals. The Capitulare de villis, a detailed account of the royal estates from the end of the eighth century gives some indication of a system of villae on royal estates kept ready and fully equipped to receive the king, and of the notice of arrival that would be expected, a bit like a system of second homes. ${ }^{14}$ Some places may only have received the king once or twice in the course of his reign, whereas he was very often at others. We have no information about the logistics, though Carlrichard Brühl has discovered a great deal about the means of supplying provisions and hospitality. ${ }^{15}$

Considerable indications of the reasons for Charlemagne's visits to places are provided by the various narrative and documentary sources, though there remain many months of many years unaccounted for. There is often uncertainty about the status of a particular place, whether as a customary resting place, temporary, occasional or unusual stopping place en route to somewhere else, or an established royal residence. ${ }^{16}$ In Italy, for instance, Charlemagne may have stayed in episcopal residences as well as making use of Lombard palaces. In Rome he probably stayed near St Peter's, though one wonders for whom the nice little Carolingian villa was built in the Forum of Nerva at the end of the eighth century. ${ }^{17}$ Occasionally another palace presents itself as very likely, such as Worms for a stay en route between Pavia and Ingelheim. ${ }^{18}$

${ }^{13}$ Gauert, 'Zum Itinerar'.

${ }_{14}$ Capitulare de villis, cc. 38, 42, 65, A. Boretius, ed., Monumenta Germaniae Historica, Capitularia I (Hannover 1883), No. 32, pp. 82-91 at pp. 86-87 and 89.

${ }^{15}$ Carlrichard Brühl, Fodrum, gistum, servitium regis. Studien zu den wirtschaftlichen Grundlagen des Königtums im Frankenreich und in den fränkischen Nachfolgestaaten Deutschland, Frankreich und Italien vom 6. bis zur Mitte des 14. Jarhhunderts, Kölner Historische Abhandlungen 14, 1-2 (Cologne; Graz 1968).

${ }_{16}$ Brühl, Fodrum, gistum, servitium regis, p. 312.

${ }_{17}$ Riccardo Santangeli Valenziani, 'Profanes Bauwesen in Rom um das Jahr 800', in: 799 Kunst und Kultur der Karolingerzeit III. Beiträge zum Katalog der Austellung, Christoph Stiegemann and Matthias Wemhoff, eds. (Mainz 1999) pp. 550-557.

${ }^{18}$ On palaces see Rosamond McKitterick, Charlemagne: The Formation of a European Identity (Cambridge 2008), and eadem, Karl der Große (Darmstadt 2008) and the references there cited. 
A royal residence appears to have been a building or estate that the king owned, and was purpose-built or designated as royal so that only the king lived or stayed there (as distinct from being a guest there). These may have included secular places that he visited as a guest of the local count, or town houses in the civitates or trading centres, such as Bardowick. ${ }^{19}$ It is certainly possible that Charlemagne would have preferred in particular instances to stay with the local bishop. At Rouen, for instance, the bishop appears to have presided over the construction of a new residence early in the ninth century. ${ }^{20}$ It is also a possibility that he could have stayed, if not in his own residence, or that of the local missus or count, then even in some kind of public hospice, with rooms commandeered for the occasion if a monastery's guest house were not within reach. The endowment of monasteries and the number of new buildings to serve the king on the move could presumably have been intended for the royal agents as well. The Capitulare de villis also related the organization of the royal estates and houses for receiving the king to the movements of the army. The produce of the estates was one of the things that would be loaded onto carts for the campaigns. ${ }^{21}$

The capitulary and narrative references to assemblies also indicate that meetings of secular and clerical magnates were frequent. In no source is there any reference to billeting on the local populace and it is likely that temporary 'tent-cities' sprang up. The advantage of camps would have been that everyone was there with horses and carts to hand and ready to move very quickly if necessary. Open spaces for camps also offered a major extension of the space within which the king moved.

${ }^{19}$ Gauert, 'Zum Itinerar', following up Carlrichard Brühl, 'Königspfalz und Bischofstadt in fränkischer Zeit', Rheinische Vierteljahresblätter 23 (1958), also said the inner organization, the function of these palaces in the itinerary, and their relationship to royal estates, royal forests and to trade and commerce should be investigated. Some discussion since 1965 has undoubtedly pursued these questions. See, for example, Inge Lyse Hansen and Chris Wickham, eds., The Long Eighth Century: Production, Distribution and Demand, The Transformation of the Roman World 11 (Leiden 2000).

${ }^{20}$ Jacques Le Maho, 'Die erzbischöfliche Pfalz von Rouen (Frankreich) zu Beginn des 9. Jahrhunderts, in: Splendor palatii. Neue Forschungen zu Paderborn und anderen Pfalzen der Karolingerzeit, Lutz Fenske, Jörg Jarnut and Matthias Wemhoff, eds., Deutsche Königspfalzen. Beiträge zu ihrer historischen und archäologischen Erforschung 5 (Veröffentlichungen des Max-Planck-Instituts für Geschichte 11/5) (Göttingen 2001) pp. 193-210.

${ }^{21}$ Capitulare de villis c. 30, MGH Cap. I, No. 32, p. 85 and see also c. 64 and 68, ibid., p. 89. 
The places apparently visited, moreover, reflect a network of social and political connections that it is sometimes possible to document in greater detail from other sources. This suggests that the distribution of royal residences across the empire needs to be seen as functioning within this network and was far from being higgledy-piggledy. ${ }^{22}$ Yet the palaces that have been identified were for the most part too far apart for us to envisage them as the only stopping place for the ruler or any of his officials. What has to be surmised, therefore, is a combination of halts by the side of the road, using tents or rough shelters, the possibly frequent use of the guest houses of abbeys or bishoprics, and use of royal estates and royal residences or palaces en route as indicated by the provisions of the Capitulare de villis. Although in some instances the route taken-by ship down the Rhine, crossing the Alps by the Great St Bernard pass, by land from Boulogne to Tours via St Riquier, Rouen and Orleans (probably on old Roman roads) is known, for many of these journeys we know only the destinations (though the exact location cannot always be identified), rather than details about the means of travel or routes followed.

If much of the itinerary of Charlemagne is to be attributed to war and the consolidation of conquest as a military leader on the one hand, and to religious devotion and the observance of Christian festivals on the other, ${ }^{23}$ it would suggest that we need to look more closely at the remainder of the evidence to establish how much, in addition to the information about assemblies, can be assigned to governmental and administrative action.

There are many aspects of Carolingian royal government and 'the court' which I cannot explore in detail here. These include the structure of the royal household, the practical evidence for its designation as a court, the stylized glimpses of a court setting offered in poems by Alcuin, Modoin, Theodulf and Angilbert in the late eighth and early ninth centuries, the religious role of the palace chapel, and the role of Aachen alongside many other administrative and ceremonial centres in Charlemagne's topography of power. Pippin III and his son

\footnotetext{
${ }^{22}$ I here differ from Stuart Airlie, 'The Palace of Memory. The Carolingian Court as Political Centre', in: Courts and Regions in Medieval Europe, Sarah Rees Jones, Richard Marks and Alaister J. Minnis, eds. (York; Woodbridge 2000) pp. 1-20.

${ }^{23}$ For fuller details on the sacred topography of Charlemagne's kingdom and the organisation of his court, as well as other aspects alluded to in the next two paragraphs, but not considered here, see the detailed discussion in McKitterick, Charlemagne.
} 
Charlemagne had undoubtedly shifted the focus of political power within Austrasia, centred on Aachen, Liège, Nijmegen and Cologne, but new residences were established in the Rhineland and Saxony at Frankfurt, Paderborn and Ingelheim. Many former Merovingian and Lombard royal residences were also taken over by Charlemagne. ${ }^{24} \mathrm{I}$ propose instead to tackle one particular hitherto rock-solid category of evidence supporting the royal itinerary, namely, the redaction of royal charters and their implications. These prove to be vital evidence in particular for the extent to which the Frankish court of Charlemagne at any stage during his reign was actually itinerant in the technical sense or functioned as a centre of communication. So, let us now turn to the question of charters and the royal itinerary.

Royal diplomas record royal business. Charlemagne's charters grant lands, royal protection, immunity, the revenue from tolls, and free abbatial election to different places. They record the settling of property disputes and the return of confiscated land. This charter evidence has appeared to scholars in the past to provide an exact and uncontestable source of information about the king's whereabouts with a simple equation: where the charter was drawn up, there was the king and his court. Unfortunately, it is not as simple as that.

Let us look at the year 775 to highlight the problems, though it needs to be registered that 775 was the year from which the greatest number of charters, twenty-two, survives in the whole of Charlemagne's reign. Between 5th January and 26th June there is a series of charters drawn up ad carisiaco palatii publici (sic), that is, at Quierzy. The dates given are 5th and 22nd January; 14 March, 4th April, 24th and 29th May, 9th and 26th June. During these six months one charter was also drawn up at St Denis (actum in monasterio) on 25th February and two at Thionville on 3rd and 10th May (apud theodonem). For the rest of the year charters are recorded at Düren 28th July, 3rd August, 25th October, and November. Thionville is recorded again in November, and the last document for the year is at Sélestat in December. The Quierzy charters record grants to Hersfeld in Thuringia, Metz, St Denis, Farfa and Honau. The St Denis documents are grants for St Denis. The Thionville documents in the early part of the year make grants to

\footnotetext{
${ }^{24}$ Günther Binding, Deutsche Königspfalzen von Karl dem Grossen bis Friedrich II (765-1240) (Darmstadt 1996).
} 
Flavigny and St Martin at Tours and in the latter part to Salonne and Prüm. The Sélestat charter records the settling of a dispute between Honau and Corbie. In the case of St Denis in February, Düren in July and Sélestat in December, the transactions are actually recorded as being drawn up or enacted at a meeting where the king was to administer justice in the place concerned. The Quierzy documents record business concerning very distant places in Germany and Italy as well as closer to Quierzy at St Denis. The two Thionville charters concern places in Burgundy and the Loire region.

Let us look at this sequence again with the distances between the various places in mind. Charlemagne spent Christmas 774 at Quierzy according to the Annales regni francorum and grants were drawn up at Quierzy in favour of Hersfeld and Metz, dated 5th and 22nd January $775 .{ }^{25}$ Next, at St Denis, $109.8 \mathrm{~km}$ or 3 days distant via Noyon and Compiègne, a charter dated 25th February (original, written by Wigbald ad vicem Hitherii) recorded land granted to St Denis. ${ }^{26}$ Then back again at Quierzy, grants were made to St Denis on 14th March of freedom from tolls and immunity. ${ }^{27}$ In 775, Easter fell on March 26th which, according to the Annales regni francorum, Charlemagne spent at Quierzy. A grant of immunity redacted at Quierzy by Wigbald was made to Murbach on 4th April. The king then supposedly moved on to Thionville, a distance of $303.5 \mathrm{~km}$ or ten-days' journey, possibly via Reims, Chalons and Metz. At Thionville, freedom from tolls was granted to Flavigny on 3rd May, and confirmation of the possession of estates to St Martin of Tours on 10th May. These charters were written by Rado but survive only in later copies. $^{28}$ Thereafter, the king apparently returned, another ten-day journey of $303 \mathrm{~km}$ to Quierzy, according to the charters of Quierzy of 24th May, 29th May, 9th June, and 26th June granting freedom of election to Farfa, confirming possessions of Honau, and of

${ }^{25}$ E. Mühlbacher, ed., Diplomatum karolinorum Tomus 1. Pippini, Carlomanni, Caroli Magni Diplomata, Monumenta Germaniae Historica Diplomata I (Hannover 1906; reprint Munich 1979) (hereafter DKar. I), Nos. 89 and 90 (both survive in the original and were written by Hitherius, and 91 (Gorze cartulary copy of s.XII; no scribe recorded).

${ }^{26}$ DKar. I, No. 92.

${ }^{27}$ DKar. I, No. 93. (This survives in a s.XII/XII cartulary), and 94 (an original, written by Wigbald ad vicem Hitherii).

${ }^{28}$ DKar. I, Nos. 96 and 97. 
earlier alienated land to St Denis. All four of these charters were written by Wigbald advicem Hitherii but only the grant for St Denis survives in the original. ${ }^{29}$ The Annales regni francorum record an assembly of the army at Düren before setting out for a summer campaign in Saxony. From Quierzy to Düren (between Aachen and Cologne) is $361 \mathrm{~km}$ or twelve days. Thereafter the Annales regni francorum records the campaigns in the Weser river region, at least ten days journey away, the capture of Syburg and the rebuilding of the Eresburg. Charters are also recorded at Düren on 28th July, 3rd August, 25th October, and November. ${ }^{30}$ The grants in July, August and October were to Hersfeld and that in November was to Fulda. Those include one original and one copy each of charters written by Rado and Wigbald, both ad vicem Hitherii. The charter of 28th July, however, was written by Theudegarius and records a settlement of a dispute between Fulrad of St Denis and Erchanrad bishop of Paris, presided over by Charlemagne, and in the presence of many fideles, including Anselm, count of the palace. ${ }^{31}$ From Düren the charter record takes us $267 \mathrm{~km}$ or nine days journey to Thionville and there Rado ad vicem Hitherii wrote a grant of land to Salonne which survives in the original in the St Denis archive. ${ }^{32}$ The Prüm cartulary records two further grants drawn up at Thionville in November, granting immunity and confirming Pippin III's gifts to Prüm. ${ }^{33}$ Lastly, at Sélestat, where Charlemagne spent Christmas 785 (according to the Annales regni francorum) a dispute was again recorded by Theudegarius in the presence of Anselm, count of the palace, and survives only in early modern copies. ${ }^{34}$ With the record of the dispute between Fulrad of St Denis and Bishop Ercanrad of Paris, this is one of the very few to record the king's presence in the charter itself. It explains that the king was in his palace in Sélestat in order to listen to cases and administer justice. ${ }^{35}$

${ }^{29}$ DKar. I, Nos. 98-101.

30 DKar. I, Nos. 102-105.

${ }^{31}$ DKar. I, No. 102.

${ }^{32}$ DKar. I, No. 107.

${ }^{33}$ DKar. I, Nos. 108-109.

${ }^{34}$ DKar. I, No. 110.

${ }^{35}$ The formula is standard: For example, in D.Kar. I, No. 102, the formula is as follows: cum nos in dei nomen Duria villa in palacio nostro ad universorum causas audiendum vel recta iudicia termenandum resederimus. In DKar. I, No. 110, it is: Cum nos in dei nomine sclatistati villa in palacio nostro ad universorum causas audiens dum vel recta iudicia terminandum resideremus. 
What does even this small example tell us about charter redaction in relation to the king's movements? The grants are a combination of royal decisions to exert patronage, and the consequence of petitions, requests for royal favour or the judicial intervention of the ruler in meetings possibly organized by the count of the palace to settle disputes. In the case of Quierzy, the Royal Frankish annals tell us that the king spent Christmas and Easter at Quierzy, so we surmise that he was there for winter and early spring before he is then recorded setting out for the assembly of the host at Düren, also a royal palace, and the campaign in Saxony. If we were to accept the charter record literally then we would have to add in the $606-\mathrm{km}$ round trip between Quierzy and Thionville in April and May. If we accept all the charters of Quierzy of 775 as an indication of the king's presence then the campaign in Saxony did not start until July. The charters issued from Düren are dated June, July, August and October which would require Charlemagne to be returning from the Weser river campaign, at least a ten-day journey, at regular intervals before finally reaching the palace of Thionville, in order to grant land to Salonne and Prüm, and Sélestat in December to judge the dispute between Honau and Corbie.

Rather than accepting the charters as an indication of the physical presence of the king, therefore, it is much more likely that we are seeing in many, if not most, instances the activities of the king's officials, with notaries and the scribes working for them sent out or based on site to record transactions in the name of the king, possibly accompanied by the count of the palace. The itinerary for the year is much more likely to have been simply from Quierzy to Düren to Saxony, back to Thionville and then on to Sélestat for Christmas (confirmed by the Annales regni francorum) before Charlemagne set out for Italy the following year, with none of the zig-zagging back and forth that the charters have hitherto been thought to record.

It would also suggest that we should take the ad vicem note in the charters more seriously as an indication of a notary acting as a deputy for the cancellarius when the latter was elsewhere. The indications are that Wigbald did indeed go to St Denis and remain at Quierzy to oversee transactions in the spring, and that both Rado and Wigbald acted for Hitherius at Düren during the Saxon campaigns of the summer and autumn.

Thus there would appear to have been a system of itinerant scribes and notaries responsible for the correct redaction and the authentica- 
tion of charters, accompanying officials for the king. The wide range of places where transactions were recorded suggests written petitions being dealt with from one of the palaces where the king has been resident at some stage, and also transactions drawn up as a result of a hearing elsewhere which had indeed been in the presence of the king. One of these is the charter of 6th December 777. It survives in the original written by Rado at Aachen, granting a privilege for the church of Salonne near St Denis, as agreed at the synod of Paderborn in the preceding summer. The meeting in Paderborn, moreover, is confirmed by the Annales regni francorum; these recorded the king holding a synodum publicum at Paderborn in spring. ${ }^{36}$

That the sequence of charters for 775 and the charter of 777 are not isolated instances is clear from other charters issued in Charlemagne's name. Use of notaries acting on behalf of the king is also indicated, for example, by the movements for 770-773. According to the various annal accounts, the king was present at an assembly in Worms in 770 with Christmas at Mainz and Herstal in the spring of 771, possibly on the way to the assembly in Valenciennes, with Christmas at Attigny in 771 and then at Herstal again for Easter in $772 .{ }^{37}$ The settlement of the dispute at Longlier in 771 is in keeping with the king's movements recorded in the narrative sources, not least the meeting at Corbeny with Carloman's followers after Carloman's death. ${ }^{38}$ It is not impossible that Charlemagne was present at Reims for the burial of his brother, for Reims, Samoussy, Attigny and Corbeny are all within one- or two-days journey from each other along the Roman road from Reims to Saint-Quentin nearby. ${ }^{39}$ The text of the Herstal charter in 772 fits the narrative record of the itinerary, for it describes the settling of a dispute about Lorsch possessions. ${ }^{40}$

Acceptance of other charters in the period $770-773$ as indications of the king's presence, however, would again involve Charlemagne in a great deal of to-ing and fro-ing, with journeys to Worms in 771

${ }^{36}$ DKar. I, No. 118. and $A R F$ 777, ed. Kurze, p. 48.

${ }_{37}$ ARF 770, 771, ed. Kurze, pp. 80 and 82.

38 DKar. I, No. 63.

39 On Carloman's burial see Annales mettenses priores 771, B. De Simson, ed. (Hannover 1905) p. 57. Samoussy to Reims is $67 \mathrm{~km}$ (2 days) and to Corbeny less than a day $(24 \mathrm{~km})$. Corbeny to Attigny is $68 \mathrm{~km}$ or two days. From the assembly at Valenciennes down to Reims would take five or six days $(172 \mathrm{~km})$.

${ }^{40}$ DKar. I, No. 65. 
and then over to Quierzy and to Longlier en route to Geneva in 773; these would have been major detours. In October 778, moreover, at Goddingas villa (Godinne) south-west of Liège, a charter to confirm St Denis's immunity was drawn up by Giltbertus ad vicem Radonis at a point when Charlemagne would still have been in Saxony, unless he took a circuitous route back from Saxony in the early autumn in order to arrive at Herstal, west of Aachen, for Christmas. ${ }^{41}$ In the following year many annals record that Charlemagne retired to Worms for the winter after the Saxon campaigns, yet there is also a charter in favour of Hersfeld drawn up at Herstal in September, by Wigbald ad vicem Radonis, many miles from either the Saxon strongholds or the palace at Worms. ${ }^{42}$ When returning from Italy in 781 to spend Christmas at Quierzy, the king travelled via Worms. He may also have gone to Herstal again on the way, to be there when an exchange of land between Abbess Eufemia of St Peter's in Metz and Fulrad, abbot of St Denis was written by one scribe and recognized by Widolaicus ad vicem Radonis. But the difference in the journeys would have been approximately $112 \mathrm{~km}$, that is, four days on the road..$^{43}$ Given the extraordinary distances traversed to Saxony or to Rome, such a detour may be entirely reasonable, but it seems less likely than the charter drawn up by the anonymous notary being sent to Herstal for recognition, or the notary visiting Herstal to get the job done in the king's absence. This is especially the case if the beneficiaries and the lands granted, themselves far removed geographically from the place of redaction, are taken into account.

Some places where charters were drawn up may well have been on the route taken and could have acted as feasible stopping places. Thus in returning to Worms from dealing with the revolt in Friuli in 776, the king may have chosen to go via Vicenza and Ivrea from which we have two charters dated 9th and 16th June on his way to cross the Alps by either Mont Cenis or, more likely, the Great St Bernard pass. Vicenza and Ivrea are approximately ten days $(314 \mathrm{~km})$ apart, though the distance might have been covered faster. Similarly, in 782,

${ }^{41}$ DKar. I, No. 120. This survives in the original.

42 DKar. I, No. 126; the editor, Mühlbacher, acknowledged this but thought there might be a mistake in the dating, p. 176.

${ }_{43}$ DKar. I, No. 136: see Alain Stoclet, Autour de Fulrad de Saint-Denis (v. 710-784) (Geneva; Paris 1993) and ChLA XVI, No. 628, Paris, Archives nationales K7, No. 8. Folradus abbas is also written in tironian notes. 
the grant recognized by Wigbald at Gondreville, if the king has to be presumed to be present, would have involved doubling back to Thionville and an extra six-days' journey at the end of the Saxon campaign that year. ${ }^{44} 786$ was a year that Charlemagne, according to all our other evidence, did not get as far north as Aachen, but Ercanbald ad vicem radonis drew up a charter there. ${ }^{45}$

Occasionally there are direct correlations between the places enjoying the king's presence in the narrative sources and the charter or capitulary record, as in the visit to Rome in 787, the Christmas and Easter 787-788 spent at Ingelheim and the assembly there on 28th March 788. There is a cluster of charters from Mainz, Worms and Kostheim during the year Charlemagne spent there in $790,{ }^{46}$ and his sojourn in Regensburg in 792 is also reflected in grants for Aniane and Aquileia drawn up there. ${ }^{47}$ Conversely, if we look at the last twenty years of Charlemagne's reign in relation both to the places of charter redaction and to the summary above of the winters spent in Aachen or elsewhere, a similar pattern emerges. From the period from 794 to 803, with no charters surviving at all for the years 796 and 798, of twentyseven charters, one third were redacted at Aachen. In the years 803, with no charters at all from 804 and 805 , and a total of sixteen surviving charters, only four were produced somewhere other than Aachen. Seven of the remainder, dated at Aachen, were written between 811 and 813 . On the charter evidence at least, therefore, it is only during the last three years of the reign that charter scribes and the now elderly king completely coincide in a prolonged residence at Aachen.

Such details are suggestive, for they undermine the solidity of assumptions about the charter evidence hitherto. Yet three further factors need to be taken into account, namely the uneven pattern of Charlemagne's charter survival, the changing pattern of charter redaction over time, and our lacunose knowledge of the royal writing office itself. These in their turn, moreover, throw further light on the functioning of the royal household.

${ }^{44}$ DKar. I, No. 147: immunity granted to Modena.

${ }^{45}$ DKar. I, No. 152, a grant of immunity and freedom of election to the abbacy for the monastery of Ansbach. This led Mühlbacher to doubt that the charter had been drawn up in Aachen.

${ }^{46}$ DKar. I, Nos. 163-167, but No. 167 for Salzburg may have been written somewhere else.

${ }^{47}$ DKar. I, Nos. 173-175. 
We have an imperfect and probably distorted impression in terms both of the geographical and chronological distribution of the charters, and of the relative intensity of charter redaction or final approval. It is dependent on the efficiency of certain archives with the chance of their documents surviving to the present day, and on the orchestration of royal favour for a particular institution. Neither can be assumed to be evenly distributed across the entire reign. ${ }^{48}$

Discussion of Charlemagne's charters hitherto has also not taken sufficiently into account either the sphere of operations of the notaries or the implications of what are known as the ad vicem and recognovi notes, supplied by the notaries, at the end of the charters. As well as the script, the formulae used, the details of what the charter was granting or confirming, and the information about where the charter was drawn up and signed, Carolingian royal diplomas provide the portion of the charter text known as the eschatocol, with the signum and name of the ruler, his monogramme and the name of the notary responsible who provides the recognovi note, that is, the official confirmation of the charter. He adds another chrismon and subscription symbol or beehive, beside which in notarial shorthand or tironian notes, the details of the recognovi note are often repeated, sometimes with additional indications of who may have requested that the document be drawn up. In a typical charter, such as that in which Charlemagne granted villas in the regions of Paris and Meaux to St Denis, there is the Signum Caroli gloriosissimi regis. Then the notary's formal recognition of the charter follows: Uuigbaldus ad vicem Hitherii recognovi and in Tironian notes is added uuigbaldus advicem Hitherii recognovi et subscripsi (that is, [I] Wigbald witnessed/validated and signed [this charter] on behalf of Hitherius). ${ }^{49}$

For the purposes of mapping both the itinerary and the activities of the scribes and notaries, it is the eschatocol and date clause which

${ }^{48}$ Daniel Sonzogni, 'Le chartrier de l'abbaye de Saint-Denis en France au haut moyen âge. Essai de reconstituion', Pecia. Resources en médiévistique 3 (2003) pp. 9-210. See also Heinrich Fichtenau, 'Archive der Karolingerzeit', in: idem, Beiträge zur Mediävistik, Ausgewählte Aufsätze 2 Urkundenforschung (Stuttgart 1977) pp. 115125, and Benoît-Michel Tock, 'La diplomatique francaise du haut moyen âge, vue à travers les originaux', in: La Diplomatique française du Haut Moyen Âge: inventaire des chartes originales antérieures à 1121 conservées en France, M. Courtois and M.J. Gasse-Grandjean, eds., ARTEM 4 (Turnhout 2001) pp. 54-60.

${ }^{49}$ DKar. I, No. 92, and Paris, Archives Nationales K6, No. 4; facsimile in: Hartmut Atsma and Jean Vezin, eds., Chartae Latinae Antiquiores XVIII, No. 615 (Dietikon 1990). 
are crucial. It needs to be stressed, however, that any chancery-trained notary, or even a scribe supplied by the recipient, could actually write the charter, but it is one of the royal notaries on his own or on the chief notary's behalf who supplies the recognovi note and subscriptio and who arranges for the seal to be attached.

The charter evidence thus provides information about the 'chancery' personnel, but the latter's relation to the royal household and to royal government, and whether the charters actually witness to the king's presence and the royal itinerary, still needs to be explored.

It may be most helpful, therefore, to consider the activities of the men who took responsibility for the production of the king's charters, and on occasion even wrote them themselves rather than relying on anonymous underlings. These can be reconstructed in chronological order of the chief notary and his named assistants. By convention the chief notary is known as the cancellarius though this term is never used by those supplying the recognovi notes and the subscriptiones in the royal diplomas of Charlemagne.

Hitherius was the head of the notaries under Pippin III and continued in this role in the early years of Charlemagne's reign. His place was taken in due course by Rado, who had himself served as a notary under Hitherius, and then Ercambald who in his turn had served under Rado. Hitherius was responsible for charters between 768 and 775 enacted at Aachen, Orville, Herstal, Valenciennes, Blanzy, ${ }^{50}$ Brumath, ${ }^{51}$ Longlier, Quierzy (773 and 775) ${ }^{52}$ and Pavia. Notaries who acted on his behalf were Wigbald and Rado. ${ }^{53}$ Wigbald was active between 774 and 782. He was responsible for charters at Düren, Samoussy,

${ }^{50}$ ChLA XIX, No. 672, Colmar, Archives départmentales du haut-Rhin, fonds de Murbach 10G generalia 3, no. 2, and DKar. I, No. 64, in favour of Murbach.

${ }^{51}$ St Gallen, Stiftsarchiv E.E.5.B.44, DKar. I, No 69, in favour of Arnald priest, and kept at St Gallen. For a facsimile see Albert Bruckner, ed., Diplomata karolinorum 1 (Basel 1974) Tafel 3.

${ }^{52}$ ChLA XII, nos. 533 and 534, Marburg Hessisches Staatsarchiv Kaiserurkunden Hersfeld 775 I 5 and 775 I 5 (redacted at Quierzy) DKar. I, Nos. 89 and 90 in favour of Hersfeld.

${ }_{53}$ Cited ad vicem Hitherii by Rado (772) at Herstal, $774 \times 6$ at Worms, Düren, Verberie, $775 \times 2$ at Thionville and Düren, and one at Vicenza by Wigbald (776). 
St Denis, Quierzy, ${ }^{54}$ Vicenza, Herstal ${ }^{55}$ Pavia, Cispliaco(?), Hersfeld ${ }^{56}$ and Gondreville. Wigbald served under Hitherius (to 776) and Rado (777-782), but the latter had done a stint as an under-notary between 772 and 783 before heading the writing office. Rado subscribed charters at Thionville, ${ }^{57}$ Herstal,${ }^{58}$ Worms,${ }^{59}$ Düren, ${ }^{60}$ Verberie, ${ }^{61}$ Patris Giagio (possibly Patri Gagio in Lombardy), Aachen, ${ }^{62}$ Quierzy, and an unidentified place..$^{63}$ At the first five of these Rado provided the recognovi notes ad vicem Hitherii.

As head of the writing office, Rado had a number of notaries working for him between 777 and 799 in addition to Wigbald. Those whose names we know include Gislebertus/Giltbertus, ${ }^{64}$ Optatus, ${ }^{65}$

${ }^{54}$ Of the eight charters Wigbald subscribed at Quierzy, three survive in the original: DKar. I, Nos. 94, 95 and 101. See ChLA XV, Nos. 616 and 617 (Paris, Archives nationales K6 5/1 and 5/2), ChLA XIX (Colmar, Archives départmentales du haut-Rhin, fonds de Murbach 10G generalia 3 no. 3) and ChLA XCV, No. 618 (Paris, Archives Nationales K6, No. 6) DKar. I, No. 101. Of these, two are from the St Denis archive in Paris and one from Murbach, now in Colmar.

55 Of the four enacted at Herstal two survive in the original: DKar. I, Nos. 116 and 123 for Fulda and St Marcel, Chalon respectively. See ChLA XII, 539 (Munich Bayerische Hauptstaatsarchiv Kaiserselekt I) and ChLA VII, No. 651 (Paris, BnF Coll. Bourgogne 75, no. 4, CL 8837).

56 DKar. I 144, for Hersfeld. See ChLA XII, No. 538 (Marburg, Hessisches Staatsarchiv Kaiserurkunden Hersfeld 782 VII 28).

${ }^{57}$ Of the four at Thionville one original, DKar. I, No. 107 for Salonne preserved in the St Denis archive, is extant. See ChLA XVI, no. 620 (Paris, Archives Nationales K6 No. 8) and 799 Kunst und Kultur, I, No. III.3. pp. 127-8. The scribe's name is recorded in tironian notes as Adarulfus, one of Fulrad of St Denis's notaries.

58 Three, including one original, DKar. I, No. 121 for Hersfeld. See ChLA XII, no. 537 (Marburg, Hessisches Staatsarchivv, Kaiserurkunden Hersfeld 779. III.13).

59 One of the two survives in the original, DKar. I, No. 130 in St Gallen. (St Gallen, Stiftsarchiv A.4.A.1, facsimile in Bruckner, Diplomata karolinorum, Tafel 4.

${ }^{60}$ Two of the four survive in the original. The St Denis archive had two copies, one subscribed by Rado and the other by Wigbald: DKar. I, Nos. 84 and 103. The former is for St Denis and the latter for Hersfeld. See ChLA XVI 613 and 614 (Paris, Archives Nationales K6 no. 5/1 and K6 no. 5/2) and ChLA XII, 535 (Marburg, Hessisches Staatsarchiv Kaiserurkunden Hersfeld 775.VIII.3).

${ }^{61}$ This survives in the original, DKar. I, No. 88, for St Denis. This is a tractoria and lacks a royal subscriptio or date clause ChLA XVI, No. 621 dated 774-776 by Atsma and Vezin (Paris, Archives Nationales K6 No. 9).

62 DKar. I, No. 118 for Salonne. See ChLA XIX, No. 679 (Nancy, Archives Départmentales Meurthe-et-Moselle G. 468).

${ }^{63}$ DKar. I, No. 83, for St Denis, preserved in the St Denis archive.

${ }^{64} \mathrm{Gi}[\mathrm{s}] \mathrm{l}[\mathrm{e}]$ bertus Writes charters from 778-781, 795. in St Denis: DKar. I, No. 120. See ChLA XVI, 620 (Paris, Archives Nationales K7, No. 3), and in Worms (x2), Lippspringe, Aachen, and Pavia: DKar. I, Nos. 128, 129, 131, 133, 151, 179.

${ }_{65}$ Optatus wrote charters in 779, 788 in Herstal and Regensburg: DKar. I, Nos. 122 and 162. See the Herstal original in Regensburg ChLA XVI, No. 625 (Paris, Archives Nationales K7, No. 2) the other survives in a s. XIII Salzburg cartulary. 
Widolaicus, ${ }^{66}$ Iacob $^{67}$ and Gudulfus. ${ }^{68}$ They subscribed charters at the palaces of Herstal, Worms, Hersfeld, Pavia, Cispliaco, Capua, Rome, and Regensburg. In addition there was Ercambald who succeeded Rado as head notary. For Rado, Ercambald provided the recognovi note and subscriptio in charters between 777 and 797 at Regensburg, Thionville, and Aachen, as well as in the cluster of palaces on the Rhine at Worms, ${ }^{69}$ Ingelheim, Mainz, Frankfurt, and Kostheim. His own charters at Aachen in 797 include one for which Maginardus acted as the ambasciator and one written by Genesius for which Ercambald supplied the recognitio. ${ }^{70}$

From 799 to 812, Ercambald had notaries under him, including not only Genesius, ${ }^{71}$ but also Amalbertus ${ }^{72}$ Hagdingus, ${ }^{73}$ Aldricus, ${ }^{74}$ Altfredus, ${ }^{75}$ Blado, ${ }^{76}$ Ibbo, ${ }^{77}$ Suavis, ${ }^{78}$ and Gilbertus. ${ }^{79}$ Apart from the

66 Widolaicus wrote charters in 781, 794 in Herstal: DKar. I, no. 136, see ChLA XVI, No. 628 (Paris, Archives Nationales K7, no. 8/1), as well as Quierzy x 2 and Frankfurt.

67 Iacob wrote from 787-792 in Capua, Rome, Worms, Regensburg.

68 Gidulfus wrote one charter in 790 at an unnamed place (no. 168).

${ }^{69}$ Of the two charters written at Worms one is original: DKar. I, No. 150 in favour of Arezzo ChLA XXV, No. 797 (Arezzo, Archivio Capitolare canonica, 783 ottobre).

${ }^{70}$ DKar. I nos 181 and 183. See also ChLA XVI, no. 637 (Paris, Archives Nationales K7, No. 15). Maginardus is probably the chaplain Maginarius, abbot of St Denis.

${ }^{71}$ Genesius wrote from 799-802 at Aachen, St Martin at Tours, Rome, the Reno river, Schweigen. The last named, in Hersfeld's favour, DKar. I, No. 198 survives in the original in the Marburg archive.

72 Amalabert wrote charters from 799 and 806 in Thionville, and Aachen in 799. Amalbertus also wrote ad vicem Ercambaldi at an unnamed place, in a charter for Lagrasse near Narbonne: D.Kar. I, No. 189. See ChLA XVIII, no. 667 (Carcassone, Archives Départmentales de l'Aude, Serie H.11, No. 1).

73 Hadingus's charter was dated at Salz and granted Grado immunity: DKar. I, No. 200.

74 Aldricus wrote one charter in 807 in Ingelheim, DKar. I, no. 206, which survives in the original. It records an exchange between Bishop Agilward of Würzburg and Count Audulf, and was also confirmed by the chaplain Hildebold.

${ }^{75}$ Altfredus wrote a charter at Aachen in 808, DKar. I, No. 207, in favour of Piacenza.

${ }^{76}$ Blado's charter written at Aachen survives in the original, DKar I, No. 208, in Modena. It confirmed Lantreicus (later altered to read Manfred) of Reggio, who had been a hostage in Francia, in possession of lands returned to him.

77 Ibbo's two charters were copied at Aachen and Verden respectively 809 and 810, and the latter, DKar. I, No. 210, in favour of the monastery of Ebersheim, survives in the original in the Municipal archive in Sélestat.

78 Suavis's two charters are from Aachen, DKar I, No. 213, an original confirming Count Bennit's ownership of land that had once belonged to his father Amalung a Saxon), see 799 Kunst und Kultur, 1, VI.5, pp. 328-9 (Münster, Nordrhein-Westfälisches Staatsarchiv, Kaiserurkunde 1,813), and an undated charter in an unidentified place in favour of Fulda.

${ }^{79}$ Gilbert's sole charter was written at Aachen: DKar. I, No. 217. 
five subscribed by Genesius's hand, and three by Amalbertis, the others were responsible for only one or two charters each and the places of redaction, apart from Aachen itself were Thionville, Ingelheim, St Martin's Tours, Rome, and a place on the Reno river near Bologna.

If these notaries are plotted on a map it becomes clear that there are different spheres and concentrations of activity as well as areasAlemannia, Aquitaine, Brittany, Saxony, Septimania and most of Bavaria and Italy - for which we have only one or two, or even no palaces recorded as places where charters were enacted, although the gifts and grants of privileges to religious institutions and to lay individuals by Charlemagne extended throughout the empire. ${ }^{80}$ The period when Hitherius and Rado presided over the notaries before 782-3 was one in which there were many charters drawn up in the palaces of west Francia, especially Quierzy, as well as outlying places such as Regensburg, Lippspringe, and Rome. Ercambald's period of office on the other hand, from 783 onwards, sees a greater concentration of charters enacted in the Rhine-Main-Moselle region and Aachen, again with outlying charters dated at Verden, Salz, Regensburg, Tours, Rome and near Bologna. It is Genesius who is responsible for the range of places from Tours to Rome. It seems likely that it was he, perhaps with some other scribes as assistants, who went to Rome as Charlemagne's secretary in 800-801, and Hadingus who accompanied the king to Salz where Charlemagne received envoys from Byzantium on his way to Bavaria. ${ }^{81}$ The notary Ibbo appears to have gone with the king on his expedition to Saxony and Verden in $810 .{ }^{82}$

There are instances in the earlier years of local scribes of charters, or scribes writing ad vicem a royal notary, that is, on behalf of a royal notary, who do not themselves seem to have been palace notaries. Two charters granting immunity and fishing and other rights respectively to Lorsch in response to requests, and drawn up at Thionville and Herstal in 772 and 777, were given the recognovi note ad vicem Liutbert (Liudberd) by Rado, which may indicate a copy had been sent to the palace to be authenticated. ${ }^{83}$ The charters also indicate

\footnotetext{
${ }^{80}$ See the maps of endowed institutions in Prinz, KdG I, p. 488.

${ }_{81}$ Compare ARF 803, ed. Kurze, p. 118 and Annales mettenses priores 803, ed. Simson, pp. 89-90.

${ }^{82}$ D.Kar. I, No. 210 and see Annales sancti Amandi and Chronicle of Moissac, G.H. Pertz, ed., MGH SS I, pp. 14 and 309.

${ }^{83}$ D.Kar. I, Nos. 67 and 114.
} 
variable documentary practice. The reports of the settlement of disputes were presented in a different style, and the notary responsible was not among the usual group of officials. Instead, he was associated with the count of the palace responsible for the record of the decisions reached ${ }^{84} \mathrm{~A}$ few of these distinctive charters survive from the reign of Charlemagne. They incorporate explicit statements about the proceedings having been conducted in the king's hearing when he was in his palace in order to listen to cases and administer justice. The groups gathered at these hearings are mentioned, such as counts and fideles listed by name, ${ }^{85}$ or the 'bishops, abbots, dukes, counts, gastalds and the rest of our faithful subjects' ${ }^{86}$ These charters are invaluable documents in affording rare glimpses of the king's judicial hearings in the course of his travels and in the presence of the disputants, witnesses, counts, scabini, fideles, and the notary, all of whom attended these hearings in the king's presence.

The charters, therefore, reflect a network of palace notaries, possibly distributed among the various royal palaces, or who at least journeyed out from a base to serve a particular region. Notaries may have had a great deal of responsibility and freedom of action, though the fact that the documents are drawn up in the king's name would imply royal approval, if not initiative. Further, the charter evidence only occasionally corroborates the presence of the king; royal diplomas reflect the conduct of royal business but are of limited value in reconstructing the royal itinerary. A great deal of day-to-day administration in the name of the king was carried out across the kingdom in the various palaces in the king's absence, even if some of these notaries actually appear to have accompanied the king himself. ${ }^{87}$

\footnotetext{
${ }^{84}$ These scribes are generally known as Gerichtsschreiber. See Bautier, 'La chancellerie royale', and R. Hübner, 'Gerichtsurkunden der fränkischen Zeit. I Die Gerichtsurkunden aus Deutschland und Frankreich bis zum Jahre 1000', Zeitschrift der Savigny Stiftung für Rechtsgeschichte, Germanistische Abteilung 12 (1891) pp. 1-118 and idem, 'Die Gerichtsurkunden aus Italien bis zum Jahre 1150', Zeitschrift der Savigny Stiftung für Rechtsgeschichte, Germanistische Abteilung 14 (1893) pp. 1-258.

${ }_{85}$ See DKar. I, No. 110.

${ }^{86}$ See, for example, DKar. I, No. 196. This is the dispute subscribed by Genesius rather than a count of palace's scribe, though the reference to dukes and gastalds is pertinent to the Italian context.

${ }^{87}$ On particular palaces and services see the Capitulare missorum 808, c. 9. de operibus palatii ad Vermeriae; c. 10. de illo broilo ad Attiniacum palatium nostrum, MGH Cap. I, No. 53, p. 140, in BnF lat. 9654 fol. 21v and BAV pal.lat. 582 fol. 24v. See also the Capitula omnibus cognita facienda 801-814 (?801-806), c. 1 ut infra regna Christo propitio nostra omnibus iterantibus nullus hospitium deneget, mansionem et focum
} 


\section{Conclusion}

By the end of the eighth century, Charlemagne's kingdom extended from Brittany to the Danube Bend, and from north of the Elbe to the duchy of Spoleto in Italy. I have argued that there are a number of fundamental problems with the customary interpretations of the surviving evidence and the consequent assessments of Charlemagne's rule of this vast realm in relation both to the functioning of an itinerant court and to the Frankish palaces, usually judged to have had a symbolic role as locations of royal power from time to time as a result of the king's residence or the conduct of royal business. The ambiguities and uncertainties of the evidence have to be acknowledged, however distressing the consequences for what historians like to think as appropriate for a ruler of most of western Europe. Any questions about the physical topography of power in the Frankish realm, furthermore, have to consider its mental counterpart in the early Middle Ages. ${ }^{88}$

Certainly, the Frankish empire ruled by Charlemagne between 768 and 814 was distinctive for the plurality of its political and administrative centres and the maintenance of communications between these centres and their surrounding regions. Yet the notion of a court itself in the early Middle Ages has proved difficult to determine once any attempt is made to find evidence to support anachronistic assumptions about a court as an institutional structure. It is even difficult to establish the scale of the royal household as a domestic unit, quite apart from the limited degree to which a Frankish royal 'court', virtual or actual, as distinct from larger assemblies, was able to act as a 'meeting place and centre of elite integration'. ${ }^{89}$ Charlemagne's 'court', even if defined merely as a group comprising family and essential officials who sometimes shared the king's current residence, is too often seen in the modern scholarly literature as a static and unchanging institution and described solely in terms of the conditions apparently prevailing during the very last few years of his half-century reign or even in those of the early years of the reign of Charlemagne's son Louis the Pious.

tantum; similiter pastum nullus contendere faciat, excepto pratum et messem, MGH Cap. I, No. 57, pp. 144; and Capitulare missorum Aquisgranense primum, c. 1: de clamatoribus qui magnum impedimentum faciunt in palatio ad aures domni imperatoris, MGH Cap. I , No. 64, p. 153.

${ }^{88}$ See Mayke de Jong, Frans Theuws and Carine van Rhijn, eds., Topographies of Power, The Transformation of the Roman World 6 (Leiden 2001).

${ }^{89}$ Again, I argue this in detail in McKitterick, Charlemagne. 
The understanding of the royal itinerary itself has also been based on ill-founded assumptions. The links between the many Frankish political and administrative centres were not in fact dependant on itinerancy. In its turn, the royal movements were not integral to the system of Carolingian government as it was developed under Charlemagne. On the contrary, an elaborate system of written and oral communications provided the essential underpinning of Charlemagne's government. At first assumed to be itinerant, the court is alleged to have 'settled at Aachen around 794', even though according to the contemporary evidence available to us, only in the last four years of Charlemagne's life, did Charlemagne remain at Aachen most of the year rather than only during the winter-a state of affairs that probably had as much to do with advancing age as with any political ideology. Aachen's place in the structures of Frankish royal power was far from being as dominant as was once supposed. That the king travelled with a small entourage is undoubted, but his journeys do not accord with the technical definition of itinerant kingship, for it was not a fundamental aspect of his method of rule. Certainly the assemblies and the meetings to administer justice were gatherings of groups of people within a locality or a region who came, or were summoned, to meet the king. The king travelled for specific purposes, to go to war, to honour a saint, to convene assemblies, and to go hunting, but the pattern of his journeys is not that of a systematic or comprehensive system of rule. Courts have been regarded as a reflection of centralized power and the centre for competition for royal favour and individual prestige. ${ }^{90}$ An itinerant court might in any case seem to be a contradiction in terms, for it implies either no centre or a variable centre, and thus a shifting kaleidoscope of power. If, on the other hand, the king and his notaries were the ones who moved, often independently of each other, it would make the personal aspects of Carolingian government potentially more prominent. The energy put into administration and justice by the king himself was emulated by the officials installed in the localities, and the elaborate system of counties and missatica (administrative districts) regularly inspected by the king's agents known as the missi dominici. ${ }^{11}$

\footnotetext{
${ }^{90}$ See Jeroen Duindam, Myths of Power: Norbert Elias and the Early Modern Court (Amsterdam 1995).

${ }^{91}$ Karl-Ferdinand Werner, 'Missus-Marchio-Comes. Entre l'administration centrale et l'adminsitration locale de l'Empire carolingien', in: Histoire comparée de
} 
Charlemagne's solution to the problem of royal control and government of his realm was thus a combination of itinerancy and stability with a complex network of officials empowered to conduct business on his behalf, so that the king himself, to adapt Stuart Airlie's evocative phrase, was 'like a great railway junction shunting personnel all over the kingdom'. ${ }^{92}$ This undoubtedly was a method of rule that developed gradually. Towards the very end of his reign and his life it is clear that the king moved about less and less and was indeed much more constantly at Aachen. This, as already noted earlier, could have been as much biological as it was ideological, for it is a pattern reflected in the careers of any number of warrior kings. In due course, however, Charlemagne augmented the powers and numbers of the missi dominici, especially in 802 , so that there would be less need for the king, let alone any of his officials other than the missi, to travel. There appears to be a greater dependence on agents and use of communications to secure rule without the king's physical presence. In other words, royal government from the royal household was increasingly dependent less on the king's own movements, for his accessibility was not the key issue, but on the effectiveness of his officials and, above all, on the means of communication.

This story has, furthermore, three obvious general morals for historians of royal courts: do not accept a proposition about the king and his court until you have checked that it was practically and physically possible; make sure that the detail supports the generalization; and do not extrapolate backwards from one apparent system on the assumption that it could apply perfectly well to others. But there is a larger point about government and statehood that emerges from this study of Charlemagne's movements. The decentralisation of political power in the post-Roman world has become a commonplace and the Carolingian 'topography' of power, partly manifested in what has aptly been described as a 'great chain of palaces', has been regarded as a model instance of such decentralization within the vastly expanded Frankish realm. ${ }^{93}$ Such perceived decentralisation has even led to

l'administration (IV ${ }^{e}-X V I I I^{e}$ siècles), Karl-Ferdinand Werner and Werner Paravicini, eds., Beihefte der Francia 9 (Munich 1980) pp. 191-239.

${ }_{92}$ The evocative phrase is from Airlie, 'The Palace of Memory'.

${ }^{93}$ See Janet L. Nelson, 'Aachen as a Place of Power' in: Topographies of Power, Mayke de Jong, Frans Theuws and Carine van Rhijn, eds., The Transformation of the Roman World 6 (Leiden 2001) pp. 217-242 at p. 222. See also again, Airlie, 'The Palace of Memory'. 
the demotion of early medieval polities as states or even as moving towards statehood. There is no particularly compelling reason why the different power structures and methods by which rulers were able to exert power over their subjects should disqualify them as states if one accepts Chris Wickham's definition of a state, viz.: 'the centralization of legitimate enforceable authority (justice and the army); the specialization of governmental roles, with an official hierarchy which outlasted the people who held official position at any one time; the concept of a public power, that is, of a ruling system ideologically separable from the ruled population and from the individual rulers themselves; independent and stable resources for rulers; and a class-based system of surplus extraction and stratification' ${ }^{94}$ Elites within such a state in the early Middle Ages were legitimized by their connection with public spheres of power..$^{95}$ This attempt to chart Charlemagne's movements has also exposed an essential part of his network of communications, and the role of particular officials with distinct responsibilities in particular places who maintained it. They were a fundamental part of the structure of his government and of the Carolingian state.

${ }^{94}$ Chris Wickham, Framing the Early Middle Ages. Europe and the Mediterranean, 400-800 (Oxford 2005) p. 57.

${ }^{95}$ See also the discussions in Stuart Airlie, Walter Pohl and Helmut Reimitz, eds., Staat im frühen Mittelalter, Forschungen zur Geschichte des Mittelalters 11, Denkschriften der Österreichischen Akademie der Wissenschaften, phil.hist. Klass 334 (Vienna 2006). This paper was delivered in the preliminary stages of writing my book, Charlemagne (2008) and it was a direct and happy consequence of Metin Kunt's request to think about the royal itinerary that encouraged me to think again about the charter evidence. I should like to record my thanks to him and to Jeroen Duindam for this opportune question. I subsequently wrote the results of this research up in detail in Charlemagne, of which the paper in this volume forms a summary. Another discussion using this same charter evidence, with the emphasis on communications in the context of Staatlichkeit, has been published as 'Court and communication in the early middle ages: the Frankish kingdom under Charlemagne', in: Walter Pohl and Veronika Wieser eds., Der Frühmittelalterliche Staat-Europäische Perspektiven, Forschungen zur Geschichte des Mittelalters 16, Denkschriften der Österreichischen Akademie der Wissenschaften, phil. -hist. Klasse 386 (Vienna 2009) pp. 357-68. 